\section{CONCERTED BEHAVIOR OF TERRESTRIAL MOLLUSKS}

ON August 29, 1915, the writer collected 125 specimens of Cochlicopa lubrica (lot 146a) from the outer surface of the door and frame of the "dark room" at the Iowa Lakeside Laboratory, on Lake Okoboji. This small frame building is more than half imbedded in the hillside about 15 feet above the level of the lake. The roof is covered with humus dirt and vegetation. A short passageway walled with heavy boards leads to the doorway.

Throughout the preceding night there had been a constant, cold rain. On the morning of the 29th there was a cold, drying wind. On the afternoon of this day I chanced to notice a specimen of Cochliciopa on the door-frame; closer examination then revealed a good many, and I spent an hour or more in gathering them. Those attached to the walls were at all heights, with the apex directly downwards, which latter fact, I presume, indicates that their movement had been upwards. None of the specimens were moving at the time, but all were retracted and fastened by a secretion to the substrate. Doubtless this condition is explained by the fact that the wind had made the planks so dry that locomotion was difficult or impossible. Ten or fifteen specimens were picked up from the ground close to the wall, but were inactive and lay as they had fallen. A few, also, were found in cobwebs, by which they had been caught as they fell from the vertical walls. While a few specimens were found on the south wall, most were on the north wall (which faced the south) and the northeast corner of the building (which faced east to north). Besides the Cochlicoper, a considerable number of specimens of Vallonia gracilicosta were found; and also about fifteen specimens of Bifidaria armifera. However, the two latter species did not exhibit any uniformity in orientation, so far as noticed, at least.

Concerning the Cochlicopo, the writer was puzzled to account, not only for their presence in rather large numbers, but for the singular uniformity of their behavior. The snails on the vertical walls were at all heights from the ground, and all exhibited precisely the same orientation, viz., the apex of the shell pointed downward. They evidently had come from the ground below. But why should they be moving upward? Under conditions of drouth and cold one would expect these forms to exhibit a positively geotropic response. Close to the water's edge among the rocks and fallen leaves the writer had been accustomed to find this species rather common; but never so many in a given area as occurred on this occasion. None had ever been found on this slope so far up, before.

It seemed to the writer that so many of these snails being found together, and with similar orientation, was a fact inviting explanation, which, however, he is unable to furnish. This case differs from the synchronic behavior recently described in Science by several authors, in that it lacks the element of rhythm. In the movement of the group of harvestmen, as described by Newman, and the simultaneous movement of the fall web-worn, described by Peairs, there is a rhythmic group movement which may be distinguished from concert of action. And while I am unable to explain the behavior of these snails, I am inclined to look upon it as a sort of concerted action.

\section{Morningside College, Sloux Citr, IA.}

\section{T. C. Stephens}

\section{A COUNTRY WITHOUT A NAME}

To the Editor of Science: I am glad to see that some one has at last had the insight and courage to note and call attention to the fact that our nation has no name. "The United States" is no name at all, and merely because we call the United States of Mexico "Mexico," and the United States of Brazil "Brazil," is no justification for calling the United States of America "America." Our brothers to our north call us "the States," which is about as meaningless as anything can be, but it is our own fault that we are so called. Some years ago there was a popular musical comedy containing a song entitled "My own United States," but it could arouse no thrill with such a handicap. Indeed we do need a national name more than a national flower, 